\title{
'De vraag is deze: waarom is een akademisch neerlandicus zulk een heel ander mens dan een nederlands letterkundige?'
}

Literatuurkritiek en literatuurwetenschap: het hoogleraarschap van Albert Verwey (1865-1937)

Marieke Winkler

NEDLET 19 (2): 97-128

DOI: 10.5117/NEDLET2014.2.WINK

\begin{abstract}
The interrelation of public and academic literary criticism often leads to controversy within the literary field, especially when writers obtain an academic position. As Jo Tollebeek showed in Mannen van karakter (2011) and Nico Laan in Het belang van smaak (1996), the competition between the academic and public discourse on literature is inherent to the history of literary studies. What are the criteria for distinguishing public and academic criticism?

This question is examined for the period 1925-1935 by taking the professorship of the poet and critic Albert Verwey (1865-1937) as a case study. Verwey legitimated his academic position by referring to Shelley and the concept of 'imagination' as a special source of knowledge. By doing so he presented an artistic and philosophical argument for appointing a poet as a professor of literature. Additionally, ten years later, Verwey revealed that he accepted the position in order to change the way literature was represented by traditional historiography. How did the activities of the poet, critic and academic relate to each other? How did Verwey position himself within, or in between, the academic and the public discourse on literature? And why does Verweys positioning problematize the relation between academic and nonacademic literary criticism?
\end{abstract}

Keywords: literary criticism, history of the humanities, discourse analysis, hermeneutics, Albert Verwey 


\section{$0 \quad$ Proloog. 'Een gast uit een vreemde wereld'}

Op 14 november 1924 werd Albert Verwey (1865-1937) bij Koninklijk Besluit benoemd tot hoogleraar letterkunde en wijsbegeerte aan de Rijksuniversiteit Leiden. Zijn leeropdracht betrof het onderwijzen in de 'Nederlandse letteren, haar geschiedenis en esthetische kritiek'. ${ }^{1}$ De benoeming van Verwey was een gebeurtenis die in de academische wereld niet onopgemerkt voorbijging. De wetenschappelijke kant van de letteren vormde een belangrijke pijler van het oeuvre van Verwey, niettemin was het ongebruikelijk dat iemand die geen academische scholing had genoten als kandidaat naar voren werd geschoven. Verwey had zijn kennis van de Nederlandse letterkunde opgedaan door zelfstudie en vanuit zijn praktijk als dichter, essayist en criticus. Reeds in 1901 was Verweys naam genoemd aan de Leidse faculteit door de hoogleraar filosofie G.J.P.B. Bolland (1854-1922) tijdens de gesprekken over de opvolging van de hoogleraar Nederlandse letterkunde Jan ten Brink (1834-1901). Bollands voorstel leidde echter niet tot een voordracht. ${ }^{2}$ In 1915 werd Verwey nogmaals, nu door een groep vrienden en bewonderaars, voorgedragen als opvolger van een hoogleraar, namelijk professor Jan te Winkel (1847-1927) in Amsterdam. ${ }^{3}$ Ditmaal wuifde het gemeentebestuur de voordracht weg als een 'absurditeit'. ${ }^{4}$ Een hoogleraar letterkunde moest van huis uit een academicus zijn, geen letterkundige - zoals Verwey het later zelf zou verwoorden in zijn afscheidscollege. ${ }^{5}$ Dan toch, in 1924, koos de oudste universiteit van Nederland ervoor een man uit de literaire praktijk tot hoogleraar Nederlandse letterkunde te benoemen.

Noch voor Verwey, noch voor zijn academische referenten lag het ambt van hoogleraar vanzelfsprekend in het verlengde van zijn functies als dichter, essayist en criticus van de Beweging van Tachtig. ${ }^{6}$ In de afsluiting van zijn inaugurele rede haalde Verwey dit punt aan:

Mijn studie is nooit op het onderwijs, maar uitsluitend op mijn dichterlijk werk en de beoordeeling van letterkundige geschriften geweest. Opleiding aan een hoogeschool heb ik nooit genoten. [...] Redenen genoeg, mijnerzijds, om niet zonder moeite tot de aanvaarding van dit ambt te besluiten. Maar het kan niet anders of die bezwaren hebben ook voor u gegolden [...] en dat ge mij nochtans voordroegt wil zeggen dat ge ze overwon. ${ }^{7}$

Verwey sprak hier zijn aanvankelijke twijfel uit of hij - man zonder academische scholing - het ambt van hoogleraar moest aanvaarden. Enerzijds oefende de universiteit een zekere aantrekkingskracht uit. Dit blijkt bij- 
voorbeeld uit het feit dat Verwey, hoewel ongevoelig voor eerbetuigingen van bestaande letterkundige verenigingen, tot tweemaal toe een uitzondering maakte voor het 'wetenschappelijk eerbetoon', zoals Voskuil belicht in 'De hoogleraar die weigerde... Albert Verwey (1865-1937) en de Maatschappij der Nederlandse letterkunde' (2012). ${ }^{8}$ Anderzijds was de universiteit een instituut waar Verwey zich niet vanzelfsprekend thuis voelde. Verwey benadrukte dit in zijn inaugurele rede door te stellen dat hij zich onder de academici nauwelijks broeder kan noemen: 'Ik schijn eerder een gast en dan nog wel een uit een vreemde wereld. ${ }^{9}$

Het domein van de academische literatuurstudie was voor Verwey duidelijk een heel andere dan het domein van de niet-academische literatuurbeschouwing. Hij sprak dan ook over twee verschillende werelden waartussen enige mate van onbegrip heerst: de literator voelde zich een vreemdeling binnen de muren van de academie. Wat waren de criteria voor afbakening van de twee werelden? Dit was niet alleen een vraag die Verwey zichzelf stelde en die tot discussie leidde rondom zijn benoeming. Het blijkt een vraag die in de vakgeschiedenis steeds opduikt en die leidt tot het voeren van een debat over de grenzen van de publieke en academische literatuurstudie en de opvattingen over 'wetenschappelijkheid' van de literatuurstudie van dat moment. ${ }^{10}$ Daarmee sluit de bestudering van de casus Verwey aan bij breder wetenschapsfilosofisch en wetenschapshistorisch onderzoek naar de grondbeginselen van de moderne geesteswetenschappen en de demarcatiestrategieën van academici in de geesteswetenschappen.

\section{Methodologie}

\subsection{Concurrerende discoursen: unieke uitspraken in institutionele context}

Verweys hoogleraarschap dient in dit artikel als casus in een analyse van de verhouding tussen het academische en het publieke discours over literatuur in de periode 1925-1935. Met 'discours' wordt hier niet meer bedoeld dan een bepaalde gereguleerde manier van spreken, in dezelfde zin als Gerald Graff de term gebruikt in Professing Literature. An Institutional History (1987): '... what teachers and students produce in literature courses is not literature but criticism - that is, discourse about literature. ${ }^{, 12}$ Het gaat in onderhavig artikel dus om het bestuderen van het kritische discours over literatuur (het gereguleerd spreken over literatuur) zoals dat binnen en buiten de academie gebruikt wordt door een specifieke protagonist. 
Een discoursanalytische (of discursieve) benadering van literaire verschijnselen is in het Nederlandse taalgebied door onder anderen Dirk de Geest geoperationaliseerd in Literatuur als systeem, literatuur als vertoog (1996) en overgenomen door Pieter Verstraeten in Het discours van de kritiek (2011). ${ }^{13}$ Deze benadering richt zich allereerst op discursieve elementen (dat wil zeggen concrete uitspraken in plaats van 'ideeën of handelingen ${ }^{14}$ ) en vervolgens op discursieve formaties (de patronen die losse uitspraken met elkaar verbinden). Voor het begrijpen van die patronen is volgens De Geest inzicht in de zogenaamde 'evenementiële' context nodig. ${ }^{15}$ Daarmee bedoelt De Geest dat de onderzoeker zich niet alleen richt op de linguïstische analyse van concrete uitspraken, maar dat hij de uitspraken plaatst in de specifieke communicatieve en historisch-culturele context waarin ze zijn gedaan. ${ }^{16}$ Verstraeten lijkt hier ook naar te verwijzen wanneer hij benadrukt dat de onderzoeker altijd bedacht moet zijn op de 'uniciteit van uitspraken.' ${ }^{17}$ In het geval van Verwey dienen de uitspraken over de eigen kritische arbeid dus niet alleen te worden begrepen in relatie tot elkaar. Zij dienen tevens te worden geplaatst in de specifieke institutionele context en de gebruiken en rituelen van de literatuurwetenschappelijke praktijk van dat moment.

Met deze aanpak wordt direct een terminologisch probleem zichtbaar. De term 'literatuurwetenschapper' werd door Verwey niet gebezigd, hij sprak - zoals hieronder zal blijken - over 'literatuurgeschiedschrijving' en 'letterkunde', en in het verlengde daarvan over 'literatuurgeschiedschrijver' en 'akademisch neerlandicus'. De term 'literatuurwetenschap' duikt in relatie tot Verwey pas op na zijn dood, namelijk in een artikel uit 1937 van C.G.N. de Vooys over 'Verwey's verdienste voor de litteratuurwetenschap' (zie $\$ 5) .{ }^{18}$ Men moet zich bij een discoursanalytische bestudering van de casus dus steeds opnieuw afvragen wat de literatuurwetenschap - in de betekenis van 'de wetenschappelijke studie van literatuur' - op een bepaald moment precies inhield en met welke termen er naar de wetenschappelijke arbeid werd verwezen.

Cultuurhistoricus Jo Tollebeek laat dit zien voor de periode rond 190o, het moment dat de academische literatuurgeschiedschrijving een zelfstandige discipline werd. In zijn studie Mannen van karakter. De wording van de moderne geesteswetenschappen (2011) belicht Tollebeek het in elkaar overlopen van het academische en publieke discours over literatuur specifiek met betrekking tot de vraag op welke manier er toen over 'verwetenschappelijking' werd gedacht. ${ }^{19}$ Als centrale protagonist voert hij de hoogleraar Jan te Winkel op en als contrapunt de essayist W.G.C. Byvanck (18481925). Van beiden vergelijkt Tollebeek concrete uitspraken over de eigen 
wetenschappelijke en publieke praktijk om op die manier inzicht te krijgen in de geesteswetenschappelijke cultuur van dat moment. Hieruit blijkt dat naast de methodische termen 'historisme' en 'positivisme', kwalitatieve termen als 'smaak', 'esthetisch gevoel' en 'visie' een prominente rol speelden. Doordat representanten van zowel het publieke als het academische discours deze begrippen hanteerden en aanspraak maakten op de genoemde kwaliteiten had de wetenschappelijke literatuurbeschouwing allerminst het monopolie op het met gezag spreken over literatuur. Dit had tot gevolg dat 'de demarcaties die de professionals als Te Winkel ten aanzien van "dilettanten" buiten het vakgebied probeerde te bewerken' niet lukte, aldus Tollebeek: 'naast het academisch-wetenschappelijke discours [bleven] ook meer publieke vormen van discours over de literatuur [...] bestaan, die met het academisch-wetenschappelijke concurreerden. ${ }^{20}$ Wat Mannen van karakter heel duidelijk laat zien is dat er van een strikte afgrenzing tussen de wetenschappelijke en niet-wetenschappelijke wereld rond 1900 geen sprake was. ${ }^{21}$

\subsection{Concurrerende discoursen, één protagonist}

Met de benoeming van Verwey wordt het bestuderen van de demarcatiekwestie nog wat ingewikkelder. We hebben hier immers niet te maken met twee afzonderlijke protagonisten die tegenover elkaar geplaatst kunnen worden, zoals Te Winkel en Byvanck, maar met een protagonist die het publieke en academische discours in zich verenigde. In zijn overzichtswerk Het belang van smaak. Twee eeuwen academische literatuurgeschiedschrijving (1997) plaatst Nico Laan Albert Verwey dan ook in een traditie die teruggaat tot de negentiende eeuw, waarin er überhaupt nog geen onderscheid werd gemaakt tussen academische, essayistische en journalistieke literatuurbeschouwing. ${ }^{22}$ Laan stelt dat er met het benoemen van hoogleraren in de moderne talen formeel een 'nieuwe vorm van literatuurbeschouwing ontstond, naast die van journalisten en essayisten', ${ }^{23}$ maar dat deze inhoudelijk amper van de niet-academische literatuurbeschouwing werd onderscheiden. Zelfs wanneer halverwege de negentiende eeuw de eerste hoogleraar Nederlandse taal- en letterkunde Willem Jonckbloet (1817-1885) een onderscheid gaat maken, blijkt de grens tussen de publieke en academische literatuurbeschouwing nog altijd minder duidelijk dan doorgaans in de vakliteratuur wordt aangenomen. Ook Jonckbloet was incidenteel als literator actief, benadrukt Laan, en 'gebruikte zijn wetenschappelijke werk om invloed uit te oefenen op het literaire debat. ${ }^{24}$

Laan trekt de lijn door naar de contemporaine situatie en stelt anno 1996 dat de wetenschappelijke en culturele intenties in de literatuurweten- 
schap nog steeds door elkaar lopen. Het is kwalijk, meent hij, dat letterkundigen

(...) geen onderscheid maken tussen hun journalistieke en hun overige activiteiten, zoals blijkt uit de opgaven voor wetenschappelijke jaarverslagen en het benoemen van mensen die zich hebben onderscheiden in de journalistiek en essayistiek. $^{25}$

De academische literatuurbeschouwer neemt geen genoegen met de metapositie van de wetenschapper, stelt Laan. Sterker, de literatuurwetenschapper wil actief meedoen 'aan de literaire en culturele strijd' en daarbij gebruikt hij als belangrijkste wapen 'de autoriteit van de wetenschap'. ${ }^{26}$ Volgens Laan wordt deze normatieve houding bij uitstek zichtbaar in het hoogleraarschap van Albert Verwey. Verwey is voor Laan dan ook geen 'vakman' maar een literator, geen academisch literatuurbeschouwer maar een essayist die de betrouwbaarheid van de wetenschap in gevaar brengt. ${ }^{27}$ Ik kom op die betrouwbaarheid terug in mijn conclusies (\$6).

Het moge duidelijk zijn dat we inmiddels terecht zijn gekomen in een demarcatiekwestie anno 1996 waarin Verwey door Laan wordt ingezet om welhaast eenzelfde soort onderscheid tussen 'professional' en 'dilettant' vast te stellen als Te Winkel deed rond 19oo. Ik wil voorkomen in dergelijke scheidsrechteruitspraken te vervallen en ik meen dat de genoemde discoursanalytische benadering daarbij kan helpen. Ten eerste doordat in zo'n benadering wordt uitgegaan van de manier waarop de protagonist zelf een onderscheid aanbracht tussen functies en bijbehorende taken, en ten tweede doordat wordt gekeken naar de beoordeling van Verweys wetenschappelijke arbeid door zijn academische omgeving. Zo kan - voor zover dat mogelijk is - voorkomen worden dat bestaande opvattingen of modellen (zoals het onderscheid tussen journalistiek, essayistiek en wetenschap) de beschrijving en analyse van de historische casus op voorhand al te zeer kleuren.

\subsection{Discoursanalytische benadering van de casus Verwey}

Om de complexe demarcatiekwestie in het geval van Verweys hoogleraarschap volgens een discoursanalytische benadering op systematische wijze te bestuderen wordt in $\S_{2}$ gekeken naar de taakstelling van Verwey: wat verwachtten Verweys collega's van zijn benoeming? Vervolgens wordt in $\S 3$ en $§ 4$ stilgestaan bij de taakopvatting en de taakuitvoering van Verwey: in hoeverre komen taakopvatting en taakuitvoering overeen? In de laatste paragraaf $(\$ 5)$ wordt gekeken naar de receptie van Verweys hoogleraar- 
schap: hoe keken Verweys 'peers' aan tegen zijn taakopvatting en de uitvoering daarvan na zijn afscheid als hoogleraar?

Voor het bestuderen van de taakopvatting is een verzameling gemaakt van Verweys uitspraken over de eigen academische en kritische praktijk (de zogenaamde metakritische uitspraken ${ }^{28}$ ) uit de periode 1925-1935 aan de hand van de bundel Albert Verwey. Keuze uit het proza van zijn hoogleraarstijd (1925-1935), in 1956 uitgegeven door Verweys dochter M. NijlandVerwey. De bundel bevat de oratie en het afscheidscollege en voorts zevenendertig stukken, waarvan het overgrote deel verscheen in het Algemeen Handelsblad en NRC, en enkele in De Nieuwe Taalgids en Tijdschrift voor Nederlandse Taal en Letterkunde. ${ }^{29}$ Het gaat om auteursschetsen (o.a. Busken Huet en Herman Gorter), om besprekingen van opnieuw uitgegeven literair werk (o.a. Bredero en Guido Gazelle, maar vooral Vondel) en om besprekingen van letterkundige studies (ook op dit gebied is Vondel prominent aanwezig). Het verzamelen van de metakritische uitspraken als basis voor de discursieve analyse ligt voor de hand omdat Verwey zich expliciet bezighield met het benoemen van het onderscheid tussen zijn academische en zijn literairkritische functie én met de vraag wat precies het verschil bepaalde tussen de werkzaamheden die bij die functies hoorden.

Voor het systematisch verzamelen van de metakritische uitspraken uit bovenstaande teksten vormden de volgende vragen de richtlijn:

a. Hoe vatte Verwey zijn taak als academicus op?

b. Hoe verschilde de academische werkzaamheid volgens hem van zijn andere werkzaamheden?

c. Welke begrippen gebruikte hij om zijn academische en niet-academische functies te typeren?

De teksten uit de bundel Albert Verwey. Keuze uit het proza van zijn hoogleraarstijd, en dan met name de oratie en het afscheidscollege waarin Verwey de taakopvatting van de academicus thematiseerde, zijn allerminst de enige teksten waarin hij zich uitlaat over wat de academische letterkundige wel of niet vermag. Als zegsman van de Beweging van Tachtig positioneerde hij zich ten overstaan van de 'officiële', 'akademische' literatuurgeschiedschrijvers in vroegere teksten als 'Toen De Gids werd opgericht' (1887), 'Het twintigste Taal- en Letterkunde congres' (1888) en 'Jan ten Brinks Geschiedenis der Nederlandse letterkunde' (1897). Medeneming van de metakritische uitspraken uit deze vroegere teksten levert een betekenisvolle aanvulling op de taakopvatting zoals geformuleerd door de hoogleraar Verwey. Voor inzicht in de taakuitvoering is voorts gekeken 
naar meta-kritische uitspraken van Verwey uit zijn collegeaantekeningen en notities uit de hoogleraarstijd. ${ }^{30}$

\section{De taakstelling van de hoogleraar Verwey rond 1925}

In de vakgeschiedenis wordt algemeen aangenomen dat de benoeming van de niet academisch gevormde Verwey werd voorbereid door diens voorganger in Leiden, de literatuurgeschiedschrijver Gerrit Kalff (1856-1923). ${ }^{3^{1}}$ Verwey en Kalff kenden elkaar vanaf ongeveer 1890 persoonlijk..$^{32}$ Op welke wijze Kalff precies een brugfunctie vervulde voor Verwey laat Dick van Halsema zien in zijn artikel "Voelers" en "weters" - Albert Verwey en de literatuurgeschiedschrijving van Jonckbloet en Kalff (1998).

Kalff observeerde in zijn Inleiding tot de studie der literatuurgeschiedenis (1914) dat er vaak een onderscheid werd gemaakt tussen kunstenaars en academische kunsthistorici en vroeg zich af: 'Waarom zou de meerdere kennis van de een niet in verband kunnen treden met dat dieper inzicht, dat nauwer geestverwantschap geeft, van den ander?'33 Hij trachtte de connectie tussen 'kennis' en 'inzicht' te bewerkstelligen door in zijn academische werk niet alleen een historisch-feitelijke en beredeneerde lezing van literaire teksten te geven, maar daarin ook ruimte te laten voor de particuliere invalshoek en smaak. Dit verklaart volgens Van Halsema dat men in de literatuurgeschiedschrijving van Kalff zowel de methode van het positivistische verklaren (het 'weten') als van het hermeneutische begrijpen (het 'voelen') herkende. ${ }^{34}$ Door zich op dit kruispunt te positioneren, werd het vervolgens mogelijk het onderscheid tussen kunstenaar en wetenschapper (in Kalffs termen: 'historicus' of 'philoloog') niet zozeer als een oppositie, maar als een accentverschil te presenteren. ${ }^{35}$ Van Halsema noemt de door Kalff voorgestelde verhouding tussen kunst en wetenschap een 'dialectisch werkverband' waarin het de taak van de dichter is om de wetenschapper 'bij de les en bij zijn onderwerp - zijn échte onderwerp [te] houden', dat is: het 'leven' van de literaire tekst. ${ }^{36}$

Al lang voor 1924 zag Kalff in Verwey de ideale dichter die de wetenschapper bij de les kon houden en die de 'nauwere geestverwantschap' de universiteit binnen kon halen. Reeds in 1916, toen Kalff hoogleraar in Leiden werd, liet hij Verwey weten dat het hoogleraarschap eigenlijk hem toebehoorde. Allereerst zou Verwey een belangrijke toevoeging kunnen leveren aan het bestaande literatuuronderwijs, want, zo had Kalff immers in zijn Inleiding geschreven 'een dichter [voelt] den geest van een dichtwerk [...] dieper en juister dan een philoloog. ${ }^{37}$ Bovendien stond 'de litte- 
ratuurstudie op 't oogenblik in het teken van internationaliteit' en Verwey had bewezen zijn 'belangstelling naar verschillende zijden gericht te hebben'. ${ }^{3}$ Terloops voegde hij nog toe dat er geen andere geschikte kandidaten waren.

Toen Verweys benoeming speelde, zo vertelde jaren nadien Geerten Gossaert (pseudoniem van professor F.C. Gerretson (1884-1958)), was er geen andere kandidaat voor de post. ${ }^{39}$ Volgens Gossaert ontstond hierdoor de ruimte voor een experimentele invulling van de leerstoel. De benoeming van Verwey was een 'proef', die niet zonder aarzelen genomen werd, maar die indien zij goed zou uitpakken, gecontinueerd zou kunnen worden. De vacature werd aldus overeenkomstig Kalffs eigen inzicht door een 'wetenschappelijk geschoold dichter-criticus' ingevuld. ${ }^{40}$

Een reactie van de dichter Hein Boeken (1861-1933) op de circulaire die in 1924 rondging onder Verweys voorstanders geeft een vermoeden van de punten waarop Verwey door zijn vrienden en bewonderaars werd aangeprezen voor de functie. ${ }^{41}$ Boeken was een oud-mederedacteur van De Nieuwe Gids maar hij was met Verwey gebrouilleerd geraakt. Sindsdien meende hij dat Verwey na Trouwmis (1887) niks fatsoenlijks meer had geschreven. In zijn ironische en duidelijk rancuneuze reactie op de circulaire maakte hij de aanbevelingen flink belachelijk. Hij antwoordde de circulaire te ondertekenen mits er in zou staan dat:

De heer Albert Verwey wordt voor het professoraat aanbevolen

${ }_{1}^{e}$ : Omdat hij in de laatste 31 jaar geen poëzie heeft voortgebracht. Er bestaat dus geen gevaar dat door de benoeming van een dichter, een dichter als zodanig ten gronde zou gaan.

$2^{\mathrm{e}}$ : De Heer Albert Verwey, die blijkens het werk zijner jeugd, grote aanleg bezat, is het beste in staat op zijne colleges te demonstreren hoe groote letterkundige aanleg nog niet voldoende is om den bezitter daarvan kunstenaar te maken en te doen blijven.

$3^{\mathrm{e}}$ : De Heer Albert Verwey is volkomen onbekend met en onvatbaar voor de literaire kunst der oudheid. Er bestaat dus geen gevaar dat hij, als Professor van de Studie in de hem toevertrouwde vakken, zou worden afgeleid door zijn liefde voor de Antieken. ${ }^{42}$

Het valt op dat het eerste punt betrekking had op Verweys dichterlijke kwaliteiten. Verwey werd dus, zoals we ook in de reactie van Kalff zagen, in eerste instantie aanbevolen op basis van zijn verdiensten als dichter. Pas in de tweede plaats kwam zijn 'groote letterkundige aanleg', waarmee Boeken lijkt te verwijzen naar de literairhistorische ambities die Verwey 
al vroeg in zijn carrière ontplooide. ${ }^{43}$ Met het derde en laatste punt lijkt Boeken te verwijzen naar Verweys preoccupatie met de eigentijdse literatuur en zijn neiging de studie van historische werken altijd te bezien in het licht van de eigen literatuur. Dat Verwey deze preoccupatie niet alleen op zichzelf maar op de academische literatuurbestudering in het algemeen van toepassing achtte, blijkt bijvoorbeeld uit een rede gehouden in 1915 tijdens de publieke ambtsaanvaarding van C.G.N. de Vooys als hoogleraar Nederlandse taal- en letterkunde in Utrecht. ${ }^{44}$ Verwey opent zijn rede als volgt:

Wie, onder onze tijdgenooten, de geschiedenis van onze letteren of de ontwikkelingen van onze taal onderwijzen zal, van hem kunnen wij vóór alles eischen dat hij voor de taal en de letteren onze eigen tijd gevoelig zij. ${ }^{45}$

In dit citaat wordt de gevoeligheid van de toegesprokene met de eigen tijd geprezen en daarmee wordt impliciet duidelijk dat Verwey dit een hoge kwaliteit acht voor een docent in de letteren. Hiermee zijn we aanbeland bij Verweys uitspraken over de eigen literairkritische praktijk en de vraag hoe hij zelf aankeek tegen de taak van hoogleraar.

\section{Taakopvatting van de hoogleraar Verwey - metakritische uitspraken in oratie en vroegere teksten}

\section{1 'Van Jacques Perk tot nu' (1925)}

In de omvangrijke studie Dáár was de bron. De Beweging van Tachtig in de ogen van Albert Verwey (1995) stelt Lucien Custers dat de benoeming van Verwey een belangrijk moment markeert in diens literairkritische carrière. In deze laatste periode trad een 'nieuwe Verwey ${ }^{46}$ naar voren: de tijdschriftredacteur, dichter en criticus die schreef voor een algemeen publiek maakte plaats voor de hoogleraar die zich richtte op een gehoor van studenten. De oratie 'Van Jacques Perk tot nu' (1925) was het eerste moment waarop Verwey zich in die rol presenteerde aan zijn nieuwe publiek, de reden waarom deze paragraaf begint met een korte bespreking van de oratie.

In de opening van zijn oratie stelde Verwey zich nadrukkelijk op als representant van de Beweging van Tachtig waarvan de dichter Jacques Perk als vroeg gestorven voorganger werd opgevoerd. Verwey stelde dat hij: 
(...) hier weinig uit mijn eigen naam en ter teekening van mijn eigen persoonlijkheid zou hebben te spreken, doch veel uit naam en ter teekening van de dichterlijke beweging met welke ik ben opgegroeid. ${ }^{47}$

Die positionering werd onderstreept door het onderwerp van zijn oratie: de Beweging van Tachtig en de vernieuwende invloed die zij had op de Nederlandse literatuur. Verwey zag zichzelf dus niet slechts als onderdeel maar als sprekend onderdeel van de Beweging van Tachtig: hij was de stem van zijn generatie.

In grote lijnen behandelde Verwey de aard van de vernieuwing die Tachtig de Nederlandse literatuur had gebracht. Hij benadrukte daarbij keer op keer de internationale context waarin de beweging moest worden begrepen. De dichters van Tachtig werden, aldus Verwey, minder dan hun voorgangers gehinderd door nationale tradities. Hierdoor kwamen zij tot andere 'verbeeldingsvormen. ${ }^{48}$ De Tachtigers richtten zich op de 'onmiddellijke gevoeligheid' van 'konkrete beelden' en drongen daarmee uiteindelijk 'het redenerend element' in de poëzie terug. ${ }^{49}$ Net als dichters in Frankrijk (Henri de Régnier) en Duitsland (Stefan George), waren de Tachtigers gericht op de werkingen van de verbeelding. Daartoe handelden zij net als hun Franse en Duitse collega-dichters volgens de uitspraak van de Britse dichter-criticus Leigh Hunt: 'Poetry is imaginative passion'.$^{\circ}$ De Beweging van Tachtig werd door de gerichtheid op de verbeelding dus ingebed in een grotere internationale ('europeesche'51) gemeenschap. Zij diende dan ook in die internationale context bestudeerd te worden. Overigens was Tachtig niet enkel een uitloper van de Engelse of Duitse romantiek, zij had tevens wortels in het eigen taalgebied. Verwey meent dat reeds in het werk van Spinoza een voorkeur voor de verbeelding als kenvermogen is te herkennen. Hiermee gaf hij de internationale tendens tegelijkertijd een basis in het werk van een gezaghebbende nationale voorganger.

In zijn oratie expliciteerde Verwey nadrukkelijk de poëtica van de internationale kunstbeweging: 'Poëzie is kunst en als zoodanig komt zij voort uit de verbeelding, die onze eenige kenwijze is voor het bizondere'. ${ }^{2}$ Met een verwijzing naar Shelleys A Defense of Poetry (1821) onderscheidde Verwey naast de kenwijze van de verbeelding (het synthetische kennen) de analytische kenwijze (het kennen door middel van de rede). Waar het verstand alleen het algemene kon bevatten, was de verbeelding in staat het bijzondere te begrijpen. Het kennen door middel van de verbeelding ging vooraf aan het verstandelijk kennen en dit werd gebruikt als legitimatie voor een hiërarchisch onderscheid tussen rede en verbeelding. Verwey articuleert dit standpunt nadrukkelijk: 
Ik bedoel hiermee dat het verstaan door middel van de verbeelding als een werkelijk verstaan begrepen wordt, en wel als een dat meer onmiddellijk dan de rede het wezen van wereld en leven bevatten zal. ${ }^{53}$

Het 'werkelijk verstaan' hoeft hier niet enkel in de betekenis van 'waar' begrepen te worden, het verwijst vooral naar een 'dichter bij de werkelijkheid' staan. De verbeelding kreeg hier dus de status van onmiddellijke bron van kennis, naast of zelfs boven het verstand. ${ }^{54}$ Even later herhaalde Verwey het onderscheid tussen de kenwijzen expliciet in relatie tot zijn toekomstige rol als docent: 'Het algemene is leerbaar [...]. Maar het bizondere - hoe zal dat worden meegedeeld, daar het toch niet anders gekend kan worden dan doordat men het ziet en ervaart?'55

Om zowel het bijzondere als het algemene te kunnen doceren was aanleg nodig, stelde Verwey. Hij formuleerde het als zijn taak de studenten vertrouwd te maken met de bijzondere kenwijze die volgens hem leidde tot 'kleurige, levende voorstellingen' van algemene begrippen. ${ }^{56}$ Omdat de blik van de dichter een 'levend zien' ('dit erkennende, ervarende, belevende zien') behelsde, was de kunstenaar bij uitstek degene die de studenten kon leren hoe het kunstvoorwerp te begrijpen 'als levend organisme'. ${ }^{57}$ De positionering als dichter was voor Verwey dus noodzakelijk voor een argumentatie, die via Shelleys Defense of Poetry ('het beste opstel over dichtkunst dat ooit geschreven is ${ }^{58}$ ), leidde tot een conclusie waaruit duidelijk werd dat Verwey een uiterst geschikte kandidaat was voor het ambt van hoogleraar letterkunde. Hij compenseerde op deze manier zijn gebrek aan academische scholing en filologische kennis met een gave die boven het strikt rationalistische weten werd geplaatst.

Toch positioneerde Verwey zich niet enkel als dichter. Veelzeggend is de manier waarop hij zichzelf in zijn inaugurele rede in of buiten de groep van de Tachtigers plaatste. Het blijkt dat Verwey over 'wij' en 'ons' sprak ('ons, jongeren van $1880^{59}$ ) als het ging om het aanvoelen van de poëticale ideeën. Hij stapte echter over op het meer afstandelijke 'zij' wanneer het ging over de bestudering van de literatuur in 'de kringen van dichters en schrijvers'. Hij schrijft hierover: 'Zij wenschten niet de geschiedenis van poëzie en proza in de eerste plaats behandeld te zien, maar voor alles proza en poëzie zelf. ${ }^{60}$ Door die distantie gaf hij impliciet aan dat hij over een wetenschappelijke, beschouwende blik beschikte, dat hij bovendien het belang van de studie van de literatuurgeschiedenis inzag en dat hij wel degelijk zijn 'verstand' kon laten spreken. ${ }^{61}$ Hiermee kwam hij tegemoet aan de wensen van zijn academisch publiek, dat zich door de claim van de dichter dat hij over een ander soort (een 'werkelijk' soort) kennis 
beschikte niet direct zou hebben laten overtuigen. Ook kwam hij zijn academisch publiek tegemoet door zich aan het slot van zijn rede netjes te conformeren aan de academische traditie door zich uitvoerig te bedienen van de gebruikelijke bescheidenheidstopoi. Tegen zijn publiek van hoogleraren zei hij: 'In alles wat aan de hogeschool geleerd wordt ben ik uw mindere' en zijn motivatie was geen andere dan de 'Dames en Heeren Studenten' van dienst te zijn. ${ }^{62}$

\subsection{Historiografische ambities in vroegere teksten}

De inaugurele rede geeft een goed beeld van de taakopvatting van de hoogleraar Verwey. Interessant is dat de in de oratie gepresenteerde tweedeling tussen de kenwijze van de verbeelding en de rede al veel vroeger aanwezig was in het literairhistorische werk van Verwey. Een van de vroegste voorbeelden is het beschouwende stuk 'Toen De Gids werd opgericht' uit 1887, verschenen in De Nieuwe Gids (en in 1897 gebundeld met nog drie andere opstellen onder dezelfde titel). In dit opstel toonde Verwey duidelijk zijn historiografische ambities en positioneerde hij zich nadrukkelijk in het domein van de officiële literatuurgeschiedschrijving. Verwey presenteerde een onderscheid tussen twee typen geschiedschrijvers. Aan de ene kant vinden we de 'chroniqueurs', zij verzamelden historische feiten en schreven die aaneen tot een chronologisch verhaal of zij rubriceerden ze in vakken en afdelingen:

Als men dan de woorden van een eeuw gehoord en haar daden gezien heeft, zal men daarmede tevreden kunnen zijn. Men zal ze kunnen opschrijven in een aaneenschakeling van: Toen kwam... en toen zei... en toen deed. Zoo schreven de meeste geschiedschrijvers; als chroniqueurs. ${ }^{63}$

Met deze werkwijze, die door Verwey werd omschreven als het ordenen en in verband plaatsen van gegevens, droeg de chroniqueur bij aan de geschiedwetenschap.

Daartegenover stond de historicus die niet alleen wilde verzamelen en verklaren maar ook wilde begrijpen. Deze term neemt in Verweys typering een centrale plaats in: 'Dat begrijpen kan men niet doen met een potlood of een methode; dat doet men met het verstand en het gevoel, waarmee men alles begrijpt. ${ }^{64}$ Verwey karakteriseerde de begrijpende geschiedschrijver als de 'artist-historicus'. Deze geschiedschrijver liet niet alleen het werk zien dat afgeleverd was in een bepaalde periode, hij bestudeerde niet alleen het uiterlijk, maar probeerde ook het innerlijk van een bepaalde tijd te doorgronden en weer te geven. In zijn arbeid was de artist-historicus gelijk 
een kunstenaar die een portret schilderde of de romanschrijver die een karakter schetste:

En als men die eeuw dan begrepen heeft, kan men haar te midden van haar arbeid rechtop in een boek zetten - zoals een kunstenaar een mensch voor ons neerzet, geschilderd of in een roman. ${ }^{65}$

In de beschrijving van de methode van de artist-historicus herkennen we direct het geisteswissenschaftliche concept van 'Verstehen', doorgaans vertaald als 'begrijpen'. ${ }^{66}$ Ook hier blijkt, net als in de oratie, een hiërarchisch onderscheid tussen de meer erklärende chroniqueur en de verstehende artist-historicus: de één had een kwaliteit meer dan de ander. Preciezer gesteld, de artist-historicus maakte niet alleen gebruik van zijn verstand maar ook van zijn gevoel in het doorgronden van 'het wezen van de tijd,. ${ }^{6}$ Het is duidelijk dat Verwey zich plaatste in het kamp van deze kunstzinnige historicus als hij stelt: 'Ik heb getracht den tijd te begrijpen, waarover ik schrijven ga. Zóo te begrijpen als ik mijn broeder begrijp of mijn beste vriend. ${ }^{68}$ Door een onderscheid te maken tussen de chroniqueur en de artist-historicus werd het mogelijk om wat vanuit wetenschappelijke hoek als een nadeel werd gezien om te zetten in een voordeel: dankzij zijn subjectivistische kunstenaarsgave was de artist-historicus beter toegerust om 'het wezen van de eeuw' te begrijpen.

Vanuit de positie van 'artist-historicus' voelde Verwey zich zelfverzekerd genoeg om de officiële literatuurgeschiedschrijvers kritisch te bespreken. In 1888 en 1889 liet hij zich in De Nieuwe Gids negatief uit over Jan te Winkel, Jan ten Brink en Jonckbloet. Het werk van Te Winkel getuigde volgens Verwey van 'lamlendigheid' en hij noemde hem een 'hals' naar aanleiding van een lezing over literaire kritiek waarin Te Winkel betoogde dat de criticus alleen 'het goede' moest aanwijzen. ${ }^{69}$ Ten Brink betichtte hij van het verkondigen van 'onzin en gemeenplaatsen', hij meende dat men hem zijn toga moest afnemen. ${ }^{70}$ Voorts wees Verwey op de schoolmeestertoon van Jonckbloet waardoor volgens hem 'de hoogheid van de kunstenaar $^{71}$ werd miskend. Die miskenning kenmerkte welbeschouwd al Verweys commentaar: hij miste in de officiële literatuurgeschiedschrijving het besef van de 'allesovertreffende belangrijkheid' ${ }^{72}$ van het dichterlijke werk zelf. De aandacht ging volgens hem te veel uit naar het ordenen van historische feiten en het rangschikken van die feiten in 'vergankelijke systemen'. ${ }^{73}$ De literatuurgeschiedschrijvers richtten zich op uiterlijkheden terwijl zij zich zouden moeten richten op het innerlijk van de literatuur.

Verwey was niet de enige literator die zich in de jaren tachtig kritisch 
uitliet over de academische literatuurgeschiedenissen. Mede-Tachtigers Willem Kloos (1859-1938) en Lodewijk van Deyssel (1864-1952) lieten zich evenmin onbetuigd in het uiten van kritiek op de ambities van de wetenschap. ${ }^{74}$ Het is in bovengenoemde voorbeelden uit de periode voor het hoogleraarschap echter duidelijk dat Verwey met zijn studies op het gebied van de literatuurgeschiedschrijving geen bijdrage wilde leveren aan de wetenschap. In de eerste plaats wenste hij een literaire traditie bloot te leggen die de eigen literatuur en de literatuur van Tachtig legitimeerde. M. Hanot constateerde in zijn studie De beginselen van Albert Verweys literaire kritiek (1957) al dat Verweys 'nood aan historische fundering' vooral voortkwam uit de wens 'in te grijpen in de waarderingsprocessen' die heersten 'in het literaire leven van zijn tijd': de geschiedwetenschap werd gebruikt om de eigen 'gedachtegang kracht bij te zetten' ${ }^{75}$ In de uitgave uit 1897 van Toen de Gids werd opgericht (1889) vinden we hiervan een duidelijk voorbeeld. Verwey meldde in de voorrede dat de essays onveranderd waren overgenomen, echter met weglating van de bijbehorende aantekeningen, want: 'Vertoon van belezenheid was toen noodig tegenover beoordelaars die zonder dat niet aan onzen ernst geloofden, tegenover lezers die vooringenomen waren tegen onze jeugd. ${ }^{, 76}$ De keuze voor het historische opstel inclusief voetnoten zorgde er met andere woorden voor dat hij serieus werd genomen. We zien hier zeer sterk wat Nico Laan signaleerde in Het belang van smaak, namelijk dat de autoriteit van de wetenschap door Verwey zelfbewust werd ingezet om de eigen literaire idealen en voorkeuren te propageren. Maar hoe zit dit nu met de oudere Verwey, kan hetzelfde zonder meer gezegd worden van de hoogleraar Verwey?

\section{Taakuitvoering van de hoogleraar Verwey - afscheidscollege, collegeaantekeningen en recensies}

Onder de noemer van de 'verbeelding' konden literatuurwetenschap en letterkunde volgens Verwey nader tot elkaar komen en kunst en wetenschap konden - in de parafrase van Van Halsema - een dialectisch werkverband aangaan waarin het beredenerend element en het verbeeldingselement in de academische literatuurstudie werden verenigd. Deze ideale voorstelling van zaken nam echter niet weg dat er institutioneel in 1935 (net als in 1925) nog steeds sprake was van twee aparte werelden. Een vermenging van de literaire en wetenschappelijke praktijk ging allicht niet zo harmonieus als Verwey misschien wel wenste. Dit zou althans de reden kunnen zijn waarom Verwey in zijn afscheidscollege 'Het lezen en 
schatten van gedichten' (1935) de volgende vraag afzonderlijk behandelde: 'waarom is een akademisch neerlandicus zulk een heel ander mens dan een nederlands letterkundige? ${ }^{77}$ Het onderscheid blijft hem bezighouden. Na tien jaar hoogleraarschap moest Verwey immers vaststellen dat de letterkundige en de academicus weliswaar hetzelfde literaire fenomeen bestuderen, maar dat de aard van hun beider onderzoek toch zeer verschillend was:

Terwijl de hoogleraar, de akademisch neerlandicus zo weinig mogelijk zijn voorkeur toont (...) en altijd weet dat het hem niet om het kritizeren, maar om het karakterizeren te doen is, geeft de nederlandse letterkundige voortdurend gehoor aan zijn eigen persoonlijke keus. ${ }^{78}$

De belangrijkste taak van de academicus was het 'karakterizeren' waar de letterkundige zich richtte op het 'kritizeren', het beoordelen van het werk vanuit de eigen voorkeur. Dit leidde er volgens Verwey toe dat de academicus zich richtte op het verleden (en de traditie) en dat de letterkundige zich bezighield met de actualiteit en de toekomst van de literatuur. ${ }^{79}$ Bovenstaand citaat werkt zeer verhelderend in het licht van de vraag naar de criteria volgens welke de publieke en academische literatuurbeschouwing van elkaar werden onderscheiden, temeer omdat Verwey hier expliciet spreekt over het beoordelen van literatuur, een activiteit die in de oratie eigenlijk helemaal niet ter sprake kwam. Nota bene wordt in de oratie wel degelijk kritiek gebezigd: niet alleen door uitspraken als 'dit is het beste opstel over dichtkunst ooit geschreven' (zie §3) maar ook, volgens Verweys eigen criteria, door de onderwerpskeuze van zijn oratie: het bespreken van de eigentijdse literatuur.

Dat het beoordelen ('kritizeren') door Verwey werd geassocieerd met de publieke en minder met de academische literatuurbeschouwing wordt bijvoorbeeld duidelijk in een recensie van J.F.M. Sterck: Het leven van Joost van den Vondel (1926). Het betreft een publieksuitgave van een uitvoerige studie over Vondel. De uitkomsten van Stercks onderzoek zijn 'boven ons lof verheven', schreef Verwey, maar Sterck kon beter laten om te schrijven over Vondel voor een breder publiek. ${ }^{80}$ Behalve dat zijn stijl onaantrekkelijk was, struikelde Verwey over de oppervlakkigheid van de beoordelingen van Vondels gedichten. De beoordelingen gaven geen 'nieuw inzicht' en waren niet 'dieper borend'. ${ }^{81}$ Kortom, Verwey diskwalificeerde de academicus Sterck als bevoegd beoordelaar van Vondels werk: 'Hij heeft tegelijk met zijn onbetwistbare bekwaamheid in het détailonderzoek, zijn sti- 
listisch tekort en zijn geringe bevoegdheid tot oordelen in het licht gesteld. $^{82}$

Toch was het hier de hoogleraar Verwey die zelf oordeelde. Dit leidde ertoe dat het eerder door Verwey gemaakte heldere onderscheid tussen de academische en publieke literatuurbeschouwing deels weer ongedaan moest worden gemaakt. Verwey vroeg zich in zijn afscheidscollege dan ook expliciet af in hoeverre het onderscheid tussen de 'karakterizerende' academicus en de 'kritizerende' letterkundige echt te handhaven was. Immers, wanneer hij naar zichzelf keek dan moest hij vaststellen dat beide persona in hem bestonden. Was het onderscheid dus:

(...) zo stellig als ik heb doen voorkomen, dan zou de ene helft van mijn wezen het moeilijk kunnen vinden met de andere. Ik moet zelfs wel verder gaan. Ik moet zeggen: er is niet alleen samenwerking, maar beide wijzen van werkzaamheid kunnen bestaan in dezelfde mens. ${ }^{83}$

Geconcludeerd moest worden dat zowel de academische als de literairkritische activiteit uitging 'van het lezen en schatten van letterkundige werken'. ${ }^{84}$ Criticus en wetenschapper vertoonden in hun praktijk meer overeenkomsten dan zij volgens hun institutionele rol zouden willen toegeven. Preciezer, Verwey zelf vertoonde in zijn academische praktijk weinig onderscheid met zijn kritische praktijk.

Hieruit spreekt de vooronderstelling dat kritiek geven (het 'beoordeelen', het 'schatten') voor Verwey onderdeel was van de wetenschappelijke arbeid. Verwey interpreteerde de leeropdracht van de hoogleraar in 'Nederlandse letteren, haar geschiedenis en esthetische kritiek' alsof de kritiek een inherent onderdeel was van de wetenschappelijke arbeid. Er zou verder onderzocht moeten worden of Verwey hier eenzelfde definitie van 'esthetische kritiek' hanteerde als zijn academische collega's, maar als we ons beperken tot Verweys invulling van de opdracht dan blijkt duidelijk dat de kritiek voor hem geen apart studieobject was. Dit wordt bevestigd in de collegeaantekeningen die zijn bewaard in het Verwey-archief. In een 'toespraak' (hoorcollege) voor zijn eerste studenten uit 1926 deelde hij mee: 'De esthetische kritiek zal ik niet afzonderlijk behandelen' ${ }^{, 85}$ en in een introducerend hoorcollege uit 1928 komt de esthetische kritiek helemaal niet ter sprake. ${ }^{86}$ De hoofdzaak van de colleges was 'de besproken werken te doen kennen, te tonen hoe men er in moet doordringen, en vooral: hoeveel men ontdekt als men zich diepgaand met een werk bezighoudt'. ${ }^{87}$ Daarnaast kregen de studenten de opdracht om op basis van de literairhistorische overzichten van De Vooys, Kalff en Prinsen hun eigen 
overzicht te maken en die 'zelfstandig op schrift te stellen'. ${ }^{88}$ Annette van Dijk bekeek voor haar studie 'Welk een ketter is die vrouw geweest!' De plaats van Albert Verwey in de Hadewijchreceptie (2009) vele collegedictaten en stelt op basis daarvan ook dat het geven van kritiek voor Verwey een geïntegreerd collegeonderdeel was: 'Esthetische kritiek, zoals die in zijn leeropdracht genoemd was, zag hij niet als een apart vak, maar als een vanzelfsprekend onderdeel van zijn colleges, dat verder niet benoemd werd. $^{, 89}$

Als we oratie en afscheidscollege vergelijken dan kunnen we vaststellen dat 'letterkundige' in de oratie door Verwey primair begrepen werd als kunstenaar - specifiek: dichter, literator - maar in het afscheidscollege vooral geïnterpreteerd werd als 'criticus'. ${ }^{90}$ Het afscheidscollege sluit Verwey af met een oproep aan academicus en letterkundige tot meer samenwerking, maar hierin lijken beide invullingen van de term 'letterkundige' te worden ingezet. Zoals de academicus de verbeelding nodig heeft om het bijzondere te zien en het literaire fenomeen echt te kunnen doorgronden, zo heeft de criticus de wetenschappelijke houding nodig om zijn persoonlijke voorkeur goed en overtuigend te kunnen onderbouwen. En dat was niet het enige volgens Verwey. De academische literatuurstudie zou het imago van de literatuurkritiek kunnen opvijzelen, zo proclameert hij, want het ontbreken van aandacht voor academische studie was 'de fout die onze letterkundige kritiek in diskrediet gebracht heeft, die het betreuren doet dat men haar geen gezag toekent'. ${ }^{11}$ Verwey maakte in zijn afscheidscollege dus zeer duidelijk wat het voordeel was van het dialectisch werkverband voor de publieke literatuurbeschouwing; het zou het publieke discours over literatuur van meer autoriteit kunnen voorzien. Bovendien werd het door het integreren van de kritiek in de wetenschap mogelijk de eigen poëtica een plaats te geven in de colleges. Dit benadrukte hij zelf door in zijn afscheidscollege nog eens terug te komen op zijn motivatie om het ambt van hoogleraar in 1925 te aanvaarden: 'De oproep immers was wel tot mij persoonlijk gericht maar zijn strekking ging veel verder: hij betekende onmiddellijke verbinding met het geslacht van '8o met een Nederlandse universiteit. ${ }^{92}$

Het lijkt erop dat algemene doelstellingen zoals het kennen van de wereld en het begrijpen van het kunstwerk volgens de methode van de verbeelding uiteindelijk een uiterst pragmatisch doel dienden: 
Alles wat ikzelf verder in deze studie gedaan had, was doordrongen geweest van de behoefte van ' 80 , het beeld van onze literatuur derwijze te wijzigen, dat in elk tijdperk het oorspronkelijk-gevormde sterker kwam te spreken dan het over-geleverde en geleerde. ${ }^{93}$

Als we kijken naar de indelingen van Verweys colleges dan wordt duidelijk wat dit impliceerde. De aandacht voor het werk van de Tachtigers is overweldigend. Niet omdat ieder college werk van een Tachtiger behandelde, maar omdat de historische literatuur (op het programma stonden o.a. Hadewijch, Van Boendale, Hooft, Vondel) altijd in verband werd gebracht met Tachtig. ${ }^{94}$ In zijn toespraak uit 1928 benadrukte Verwey dat het letterkundig onderwijs altijd gericht was op de historische en taalkundige inbedding, maar dat met zijn benoeming erkend werd dat 'literatuur nog iets anders [was] dan taal', namelijk een 'levens- en verbeeldingsuiting'. ${ }^{95}$

Bekijken we Verweys pleidooi voor een harmonieus samenwerken tussen academicus en letterkundige in de termen van Tollebeek dan valt op dat Verwey zichzelf presenteerde als bewijs van een succesvolle vermenging van het publieke en het wetenschappelijke discours: zijn praktijk als hoogleraar betekende de ideale symbiose van 'verbeelding' en 'rede', van 'karakterizeren' en 'kritizeren'. Toetsen we deze taakstelling aan de taakuitvoering dan kunnen we niet anders dan concluderen dat Verwey het voordeel van het dialectisch werkverband voor de publieke literatuurbeschouwing zeer duidelijk schetste, maar dat de waarde ervan voor de literatuurwetenschap veel onduidelijker bleef. Wat nu kan de waarde zijn van de voorgestelde samenwerking die uitstijgt boven de 'propaganda' van de eigen literaire waarden? Om dit beter te kunnen begrijpen is het niet voldoende alleen naar Verweys uitspraken of praktijk te kijken, maar moeten we ook de receptie van Verweys academische praktijk in ogenschouw nemen.

\section{Receptie - de hoogleraar Verwey in institutionele context na 1935}

Voor een indruk van de manier waarop Verwey als academicus werd gewaardeerd heb ik mij hier beperkt tot documenten die verschenen na Verweys emeritaat en niet te ver na diens overlijden in 1937, waarin iets gezegd wordt over Verweys wetenschappelijke verdienste. ${ }^{96}$ Twee artikelen van De Vooys uit 1935 en 1937 bleken zeer inzichtelijk net als het hoofdstuk dat de Nijmeegse hoogleraar Gerard Brom (1882-1959) in zijn Ge- 
schiedschrijvers van onze letterkunde (1944) aan Verwey 'en zijn school' wijdde. Het eerste artikel van De Vooys, getiteld 'Verwey's verdienste voor de Nederlandse litteratuurstudie', verscheen in een speciaal-nummer van De Nieuwe Taalgids naar aanleiding van Verweys afscheid als hoogleraar. De Vooys' tweede artikel, getiteld 'Albert Verwey en de Nederlandse litteratuurwetenschap', stond in een Verwey herdenkingsnummer van De Stem (1937) en herhaalde voornamelijk de argumenten uit de eerdere tekst.

Zowel De Vooys als Brom onderschrijft in de eerste plaats het beeld van de artist-historicus. Naast een nauwkeurig geleerde bleef Verwey voor De Vooys vooral de dichter die over literatuur schrijft:

\section{(...) in verbeelding meelevend en meevoelend, bewonderend op grond van} geestverwantschap, tijd en omgeving, door suggestieve trekjes, door typerende anecdoten of citaten voor de lezer oproepend. ${ }^{97}$

De Vooys benadrukt dat Verwey dankzij zijn dichterlijke aard kon laten zien hoe een 'studie van binnenuit' uitgevoerd moest worden, iets wat hij bovendien succesvol had doorgegeven aan zijn promovendi W.A.P. Smit, Th. Weevers, M.H. De Haan en J.M.C. Bouvy. Ook Brom bewierookte de 'bezielde' methode van Verwey die het voor elkaar kreeg 'eeuwen oude verzen opeens modern te maken'. ${ }^{8}$ Helemaal in lijn met het beeld van de artist-historicus noemt Brom Verwey 'de gevoelige onder de kenners en de verstandelijke onder de dichters'. ${ }^{99}$ Verweys invloed op de universiteit noemde Brom een 'hervorming' die hij samenvatte als: 'Van een leerzame herinnering werd onze literatuur eindelijk een levende schoonheid. ${ }^{100}$

Opvallend is dat De Vooys en Brom Verweys verdienste benoemden in relatie tot de studie van de oudere literatuur. Eén van de belangrijkste vernieuwingen die Verwey de literatuurwetenschap immers bracht, was de studie van de meer recente literatuur. Dit benadrukken ook Liauw \& Van de Zande in hun vakgeschiedenis Aan doorluchtige voorgangers hapert het niet (1996):

Vóór Verwey werd er uiteraard wel aandacht besteed aan de nieuwere literatuur, maar men was van mening dat die moderne werken tot het gebied van de kritiek behoorden en niet tot dat van de literatuurgeschiedenis. ${ }^{101}$

Bij De Vooys noch bij Brom werd Verweys verdienste met betrekking tot de uitbreiding van het curriculum richting de contemporaine Nederlandse literatuur genoemd. Overigens treffen we bij hen ook niet de opvatting aan dat de behandeling van moderne werken tot het gebied van de kritiek 
zou behoren. ${ }^{102}$ Verweys verdienste lag wat hen betreft op het gebied van de oudere letterkunde en dan voornamelijk op didactisch niveau: de oudere literatuur werd door Verweys 'bezielde' benadering toegankelijker gemaakt voor een eigentijds publiek. Het was een waardering die we al aantroffen bij Kalff.

Een andere vernieuwing die Verwey de academische literatuurstudie bracht, en die niet genoemd werd door zijn tijdgenoten, was het loskoppelen van de taal- en de letterkunde. ${ }^{103}$ Dat Verwey dit zelf als een grote verandering zag, blijkt uit de collegeaantekeningen. Zijn hoorcollegereeksen startte Verwey meer dan eens met een positiebepaling. In een introducerend college stelde hij dat met zijn benoeming het moment was aangebroken waarop de letterkunde zich emancipeerde van de taalkundige benadering. Werd de letterkunde door zijn voorgangers als 'hulpmiddel' gezien van de taalkunde, zo legt Verwey zijn studenten uit, dan draait hij die verhouding om. Deze drang naar een 'niet-taalkundige behandeling van de letteren' kwam voort uit 'de schrijvers- en leekenwereld', niet uit de universiteit. ${ }^{104}$

Verwey introduceerde een manier van spreken binnen de universiteit die was geënt op een eigentijdse literatuuropvatting. Dit had gevolgen voor zowel het curriculum als voor de verhouding tussen de letterkunde en de taalkunde. Verder onderzoek is vereist om aan te tonen of Verwey daadwerkelijk een trendbreuk bewerkstelligde in de vakgeschiedenis. Hier kunnen we concluderen dat Verwey vanuit zijn specifieke literatuuropvatting het academische discours veranderde.

\section{Conclusies: kernbegrippen, patronen en open plekken}

\subsection{Hermeneutiek}

In het voorgaande werden Verweys metakritische uitspraken beschreven in hun institutionele context. Uit de beschrijvingen is een aantal kernbegrippen naar voren gekomen dat de wijze karakteriseert waarop Verwey een onderscheid aanbracht tussen kunst (meer precies: poëzie) en wetenschap, maar óók tussen wetenschap en kritiek. Hoe hingen die begrippen precies met elkaar samen?

Het werd duidelijk dat het verbeeldings-begrip een centrale rol speelde. Het wordt door Verwey zowel poëticaal als ontologisch ingezet: de verbeelding was niet alleen de grond van waaruit de poëzie ontstaat, maar ook een manier om bijzondere kennis van de werkelijkheid op te doen. ${ }^{105}$ Het onderscheid tussen een meer verklarende en een meer begrijpende onder- 
zoeksattitude vormde een belangrijk, zo niet het belangrijkste thema van Verweys inaugurele rede. Op deze manier verbond hij zijn beeld van Tachtig niet alleen aan een internationale kunststroming, waarvan Shelley de onbetwiste woordvoerder was, maar ook aan een zeer bepaalde kenwijze. De poëzie, het object van studie, is als een synoniem voor de verbeelding een kenmiddel op zich. Het verschafte de literatuurlezer toegang tot het 'bizondere' aspect van de werkelijkheid. Hiermee is meteen een tweede belangrijk begrip genoemd.

Het bijzondere dat enkel via de verbeelding kon worden geopenbaard was, anders dan het algemene, aan tijd en plaats gebonden. Dit kennen volgens de verbeelding was een 'onmiddellijker' kennen van de werkelijkheid dan het kennen via de rede. Het werd niet door vooropstellingen gehinderd en kon daardoor dieper 'verzinken' of 'indringen' in het gedicht of prozawerk. Door het belevend kennen kon men verder dan het uiterlijk van het werk zien en leerde men het innerlijk van het literaire werk begrijpen. Het ging dus niet alleen om een be-leven maar ook om in-leven. Voor deze beschouwingswijze waren een zeker talent en een gevoeligheid vereist. Het algemene kon men leren, maar om ook het bijzondere te doorgronden had men 'aanleg' nodig. Wanneer het de beschouwer niet lukte het kunstwerk te beleven dan 'haperde zijn aanleg' of werd hij belemmerd door het reeds geleerde: het 'erkennende, ervarende, belevende zien moet zoo sterk zijn dat alle andere indrukken, voorstellingen, overwegingen tijdelijk worden buitengesloten'. ${ }^{106}$

Een derde begrip, dat tevens in dit citaat werd benadrukt, is de 'beleving'. De literatuurbeschouwer was geen afstandelijke, neutrale onderzoeker maar zette zijn gevoeligheid in om het kunstwerk te doorgronden. Deze methode paste in een traditioneel hermeneutisch kader waarin de onderzoeker zichzelf als onderzoeksmiddel inzet om zijn object te doorgronden ${ }^{107}$ Hierdoor wordt juist getracht de afstand tot het object of de maker ervan te verkleinen om op die manier het kunstwerk van binnenuit te begrijpen.

Bovengenoemde drie begrippen (de verbeelding, het bijzondere, de beleving) komen in het academische domein samen in de figuur van de artist-historicus. De metafoor van de wetenschapper als kunstenaar vormde een rode draad in de metakritische uitspraken van Verwey. Hij voerde al in 'Toen De Gids werd opgericht' de geschiedschrijver als portretschilder op en in zijn oratie positioneert hij zich, zoals we zagen, nadrukkelijk als dichter en als de kunstzinnige leraar die een gids kan zijn voor de studenten in het tonen van het bijzondere (net zoals de dichter Shelley een leraar was voor hemzelf). De samenhang tussen de verschillende begrip- 
pen wordt in de metafoor van de wetenschapper als kunstenaar zeer duidelijk, ze vormen een hecht kluwen van elkaar versterkende eigenschappen en kwaliteiten. In deze voorstelling van zaken behelsde het onderscheid tussen de dichter en de literatuurhistoricus geen absolute tegenstelling. Het ging eerder om een accentverschil, zoals Van Halsema stelt, dat de weg effende naar een dialectisch werkverband.

We kunnen met andere woorden stellen dat in de metafoor van 'de wetenschapper als kunstenaar' duidelijk wordt dat de 'akademisch neerlandicus' en 'nederlands letterkundige' niet twisten vanuit verschillende grondslagen maar vanuit verschillende conventies. Wanneer dit eenmaal onderkend is, blijkt het onderscheid tussen wetenschap en kunst een schijnonderscheid en blijft een vruchtbare samenwerking tussen rede en verbeelding, tussen feitenverzameling en schoonheidsbegrip mogelijk, en een academische bestudering van de literatuur die niet alleen het uiterlijk maar ook het innerlijk van het kunstwerk begrijpt.

Er is echter één cruciaal aspect dat in deze voorstelling van zaken veronachtzaamd wordt en dat is het gegeven dat de term 'letterkundige' twee verschillende betekenissen heeft. Enerzijds verwees Verwey met de term naar de kunst (de dichter uit de oratie) en anderzijds naar de kritiek (de criticus uit het afscheidscollege). Het 'kritizeren' wordt echter in de voorstelling van het dialectisch werkverband helemaal gladgestreken. Met het 'kritizeren' is een laatste, essentieel begrip genoemd dat van groot belang is wanneer we meer inzicht willen krijgen in de manier waarop in de periode van Verweys hoogleraarschap de publieke en de academische literatuurstudie van elkaar worden onderscheiden.

\subsection{Kritiek}

Zoals in $\S_{4}$ en $\S 5$ belicht, werd de kritische agenda van Verwey niet direct als een probleem of als een bedreiging gezien van de academische werkzaamheden, simpelweg omdat de kritiek onderdeel was van de taakomschrijving van de hoogleraar letterkunde. ${ }^{108}$ Verwey bleek de mogelijkheden van zijn taakstelling goed uit te buiten; hij maakte ten volle gebruik van de ruimte om zijn eigen literaire voorkeuren meer aandacht te geven en gebruikte de autoriteit van de wetenschap om zijn eigen poëticale standpunt meer gezag te geven. Dit is voor Liauw \& Van de Zande reden te stellen dat door Verweys benoeming de literaire kritiek 'stilzwijgend boven de geschiedschrijving van de Nederlandse letterkunde' werd gesteld. ${ }^{109} \mathrm{Na}$ bovenstaande analyse is het de vraag of dit werkelijk zo is.

Liauw \& Van de Zande lijken te vergeten dat de kritiek altijd al onderdeel van de literatuurwetenschap was. Laan onderkent dat het geven van 
kritiek wel degelijk onderdeel is van de literatuurwetenschappelijke traditie, maar toont zich tegelijk zeer afkerig van deze taakopvatting (zie §1). In de slotparagraaf van zijn overwegend beschrijvende studie spreekt Laan zich buitengewoon kritisch uit. De wens om deel te nemen aan het actuele literaire debat brengt volgens hem een al te normatieve houding met zich mee die de 'betrouwbaarheid' van de academische arbeid in gevaar brengt:

Verwey lijkt met die letterkundige invloed geen moeite te hebben. Zij is in ieder geval voor hem geen aanleiding de betrouwbaarheid van de neerlandistiek in twijfel te trekken. Institutionele onderzoekers doen dat wel en terecht. Schrijvers zijn immers, net als journalisten en essayisten, belanghebbenden. Ze stellen zich andere doelen dan onderzoekers en worden ook op grond van andere criteria beoordeeld en een 'samenwerking' tussen beiden - waar Verwey over spreekt - is dus uit den boze. ${ }^{110}$

Laan benadrukt dat de schrijver en de wetenschapper andere doelen en andere belangen hebben en dus andere strategieën ontplooien om tot hun doel te komen. De dubbelfunctie van de letterkundige heeft volgens Laan wel degelijk invloed op de wetenschappelijke integriteit van de neerlandistiek; zij zorgt ervoor dat een niet-wetenschappelijke strategie (ik zou hier liever zoals in $§ 6.1$ van conventie spreken) de wetenschappelijke wereld wordt binnengehaald. Deze niet-wetenschappelijke conventie wordt alleen maar meer aangemoedigd door de incorporatie van de studie van de hedendaagse literatuur, meent Laan. Hij stelt dat literatuurwetenschappers er beter aan zouden doen zich niet met hun literatuuropvattingen te vereenzelvigen, daarentegen zouden zij er 'verstandiger aan doen die opvattingen te analyseren'. ${ }^{111}$ Uit Laans evaluatie blijkt dat voor hem niet de 'inleving' of de vereenzelviging maar de 'beschrijving' of de analyse het adagium is van de wetenschapper. De literaire kritiek dient volgens hem geen geïntegreerd onderdeel te zijn van de literatuurstudie maar een duidelijk afgebakend onderzoeksobject. Ook bij De Geest vinden we verwante uitspraken. Zo schrijft hij dat '[d]e persoonlijke betrokkenheid van de individuele historicus bij zijn onderzoek' heden ten dage veel nadrukkelijker wordt geproblematiseerd en dat vooral 'het formuleren van eigen waardeoordelen [...] met een zekere terughoudendheid [wordt] benaderd ${ }^{112}$ en ook hierop volgt een demarcatie: 'Het gros van de publicaties op het gebied van de recente Nederlandse literatuur geldt in literatuurwetenschappelijke kringen als verdienstelijke doch uiteindelijk onwetenschappelijke essayistiek.'113

Hieruit moeten we afleiden dat specifiek het kritische aspect in de lite- 
ratuurwetenschap in de studies van Liauw \& Van de Zande, Laan en De Geest - en in zekere zin door de auteur dezes, want anders zou de vraag die in dit artikel gesteld wordt niet gesteld zijn - als problematisch wordt gezien voor de wetenschappelijke status van de academische literatuurstudie. Het uitoefenen van kritiek maakt de wetenschap normatief en daardoor onbetrouwbaar. Voor De Vooys en Brom speelde deze negatieve waardering van normativiteit van de literatuurwetenschapper nog geen rol. Zij reppen niet over de gevolgen van Verweys kritische arbeid voor de uitvoering van de wetenschappelijke arbeid en volgen min of meer diens eigen standpunt in dezen. Deze observatie zegt net zo veel over het dominante beeld van de literatuurwetenschap ten tijde van Verweys hoogleraarschap als over het beeld van de literatuurwetenschap anno nu. We zien namelijk in de genoemde studies uit de jaren negentig een duidelijk andere wetenschappelijke conventie: het lijkt erop dat sinds de jaren tachtig een zeker onbehagen is ontstaan met de traditionele kritische taakopvatting van de literatuurwetenschappelijke arbeid. ${ }^{114}$ Dit ongemak verklaart tevens de hernieuwde aandacht voor de vakgeschiedenis in de jaren negentig, waarbij meteen duidelijk werd hoe weinig werk de letterkundige neerlandistiek op dit gebied heeft verricht. ${ }^{115}$

Ik heb getracht in dit artikel - voor zover dat mogelijk is - geen partij te kiezen voor of tegen het normatieve aspect in de literatuurwetenschap, maar ik heb gekeken welke begrippen door Verwey werden gearticuleerd in het begrijpen van de eigen taak, en naar wat de patronen in het gebruik van die begrippen ons vertellen over de gronden van waaruit het publieke en academische discours over de literatuur met elkaar concurreren ten tijde van zijn hoogleraarschap. Door zijn vele uitlatingen over doel en functioneren van de literatuurstudie heeft Verwey, niet alleen in de hoedanigheid van dichter en hoogleraar, maar juist óók in de hoedanigheid van criticus, een belangrijke bijdrage geleverd aan het construeren en conceptualiseren van de concurrentiestrijd.

Het aanbrengen van een onderscheid tussen literatuurkritiek en literatuurwetenschap blijkt tot de dag van vandaag een effectieve strategie voor wetenschappelijke demarcatie: door het verschil te benoemen benadrukt men immers de eigen identiteit. Het onderzoeken van de relatie tussen literatuurkritiek en literatuurwetenschap vormt op die manier een uitgelezen onderwerp om de geschiedenis van de literatuurwetenschap nader te onderzoeken. Het huidige onbehagen met de als normatief ervaren aspecten van de literatuurwetenschap en het sinds de jaren negentig gevoelde gemis van een vakgeschiedenis die dit normatieve aspect van de literatuurwetenschap in perspectief kan plaatsen, bewijst dat een dergelijk onder- 
zoek naar de positionering van de literatuurwetenschapper door de tijd heen meer dan gewenst is.

\section{Noten}

1. Van Dijk (2009), 275 .

2. Van Halsema (2010), 383 .

3. Voskuil (2012), 29.

4. Uyldert (1959), 132-133.

5. Verwey (1956), 262.

6. Van Dijk (2009), 275-276.

7. Verwey (1956), 31.

8. Voskuil (2012), 29. Het gaat hier om een eredoctoraat in de Nederlandse letterkunde dat Verwey werd toegekend in 1914 door de Rijksuniversiteit Groningen en om een in 1936 toegekend erelidmaatschap van de Koninklijke Vlaamsche Academie.

9. Verwey (1956), 31 .

10. Zie in het bijzonder Laan (1997), maar ook Anbeek (1997) en Fokkema \& Ibsch (1992).

11. Zie o.a. Abma (2011); Bod (2010); Goldmann e.a. (2007); Johannes (2011); Tollebeek (2011).

12. Graff (1987), xvii.

13. De Geest gebruikt zowel de term 'discursief als 'discoursanalytisch' om zijn benadering te typeren, Verstraeten spreekt van een 'discoursanalytische benadering'. Beiden verwijzen met de term naar de Franse discourstheorie die teruggaat op Michel Foucaults essay L'ordre de discours (1971) en zijn beroemde werk L'archéologie du savoir (1969).

14. Verstraeten (2011), 39.

15. De Geest (1996), 163 .

16. Overigens zijn discursieve elementen zeker niet het enige middel om inzicht te verkrijgen in de manier waarop de protagonist zichzelf positioneert. Ook niet-tekstuele of visuele aspecten kunnen waardevolle inzichten geven in de zelf(re)presentatie van de protagonist. Zie bijvoorbeeld het begrip 'posture' van Jerome Meizoz, in de neerlandistiek geoperationaliseerd door o.a. Gillis Dorleijn (2009). Ook Tollebeek (2011) neemt visuele aspecten, zoals geïnstitutionaliseerde portretten van de wetenschapper, mee in zijn analyse.

17. Verstraeten (2010), 39 .

18. Als zelfstandige academische discipline bestaat de literatuurwetenschap pas sinds 1956, met de benoeming van Hans Teesing in Utrecht als eerste hoogleraar Algemene literatuurwetenschap. Zie Liauw \& Van de Zande (1996) en Goedegebuure \& Heynders (1996).

19. Tollebeek (2011), 10.

20. Tollebeek (2011), 26-27.

21. Tollebeek benadrukt dat deze situatie niet alleen de letterkunde betrof. Ook de sociale wetenschappen kampen met het probleem dat het spreken over sociale ontwikkelingen niet voorbehouden was aan de sociale wetenschappen, maar ook gebeurde vanuit de politiek, het bedrijfsleven en binnen allerlei sociale verenigingen. Zie bijvoorbeeld Abma (2011) over de problematische 'dubbele legitimering' van de sociale wetenschappen. 
22. Laan maakt hier een onderscheid tussen journalistiek, essayistische en academische kritiek. Eenzelfde driedeling vinden we bijvoorbeeld in Dorleijn \& Van Rees (2006) en in het buitenland bij Rosengren (1987). Toch moeten we op dit punt ook bedacht zijn op het feit dat deze driedeling recenter is dan de besproken periode.

23. Laan (1997), 41.

24. Laan (1997), 53. Laan noemt Jonckbloet 'de eerste literatuurhistoricus in ons land die een onderscheid maakte tussen een academische en niet-academische beschouwingswijze' Laan (1997), 43. Zie ook Van Oostrom (1989).

25. Overigens zijn ook in het publieke domein de grenzen vervaagd doordat 'de meeste recensenten, anders dan vroeger, geen schrijver meer zijn en eveneens Nederlands gestudeerd hebben' Laan (1997), 230. We kunnen in dit licht ook denken aan colleges Creative Writing die vooral in de Angelsaksische wereld veel gedoceerd worden aan letterenfaculteiten en waarvoor gerenommeerde schrijvers worden aangetrokken. Aan Nederlandse universiteiten vinden we weliswaar 'writers in residence', maar Creative Writing is niet opgenomen in het curriculum.

26. Laan (1997), 230.

27. Laan (1997), 231 en 274. Laan stelt dat de traditie van 'hoogleraar-literaten' die in Leiden was ingezet met de benoeming van Verwey eindigde in 1981 toen Hans Gomperts (1915-1998) met emeritaat ging.

28. Term overgenomen van Praamstra (1984).

29. Voor een uitvoerige bibliografie van Verweys kritische werk zie Hanot (1957).

30. Deze bevinden zich in het Albert Verwey-archief van de Bijzondere Collecties van de UvA.

31. Zie Brom (1944), Liauw \& Van de Zande (1996) en Laan (1996). Dit beeld komt ook terug in Van Dijk (2006).

32. Verwey spreekt in zijn oratie over hun vriendschap die 'tusschen de dertig en veertig jaar' omspant. Verwey (1956), 25. Zie ook Uyldert (1959).

33. Kalff geciteerd door Luger (1989), 338. In een speciaal nummer van Literatuur over de 'erflaters van de Nederlandse literatuurgeschiedenis'.

34. Van Halsema verwijst hiervoor ook naar Luger (1989) en Spies (1984).

35. Van Halsema (2010), 382. 'In feite hebben ze elkaar nodig: de voeler kan pas tot de juiste voeling komen als de weter met zijn onderzoeksbuit is thuisgekomen. Maar dan kan, op zijn beurt, de voeler op basis daarvan tot inzichten komen waaraan de weter weer niet kan reiken.'

36. Van Halsema (2010), 381 .

37. $\operatorname{Kalff}(1914), 126$.

38. Van Halsema (2010), 384-385. Aantekeningen van Verwey over gesprek met Kalff: XLI A 23:69.

39. Gossaert (1957), 51 .

40. Ibidem.

41. De circulaire heb ik tot op heden nog niet kunnen traceren.

42. Reactie van H.J. Boeken opgenomen in Uyldert (1959), 286.

43. Van Halsema noemt het essay 'Het sonnet en de sonnetten van Shakespeare' (1885) een eerste teken van Verweys studieusheid. Van Halsema (2010), 377.

44. Van Halsema noemt De Vooys veelbetekenend één van Verweys 'eigen jonge neerlandici'. Van Halsema (2010), 381. De Vooys' reputatie als hoogleraar zou groot worden. Niet alleen voor de studie van de neerlandistiek in Utrecht, ook voor de neerlandistiek in het algemeen was zijn hoogleraarschap van belang. Zie o.a. Van Haeringen (1956) en Gerritsen (1996). 
45. Verwey (1923), 45 .

46. Custers (1995), 15. Deze typering wordt overgenomen door Van Dijk (2009).

47. Verwey (1956), 12.

48. Verwey (1956), 16.

49. Verwey 1956), 16.

50. Verwey (1956), 17 .

51. Verwey (1956), 21.

52. Verwey (1956), 25.

53. Verwey (1956), 19 .

54. Zie ook Custers (1995), 45 en in het bijzonder Johannes (1992).

55. Verwey (1956), 25.

56. Verwey (1956), 33 .

57. Verwey (1956), 26 .

58. Verwey (1956), 17.

59. Verwey (1956), 21.

6o. Verwey (1956), 25.

61. Overigens benadrukken Hanot (1957), Custers (1996) en Van Dijk (2009) allen dat Verweys studie altijd in dienst heeft gestaan van de eigen literatuur en nooit een doel op zich was.

62. Verwey (1956), 31.

63. Verwey (1897), 10.

64. Ibidem.

65. Ibidem.

66. Zie Leezenberg \& De Vries (2001).

67. Het moet hier opgemerkt worden dat de termen 'gevoel' en 'verbeelding' nog al eens door elkaar lopen bij Verwey. Zie Johannes (1992). In Verweys opstel 'Nog eens iets over Beets en zijn laatste bundel' (1884) worden de twee zelfs aan elkaar gelijk gesteld. Zie Custers (1995), 43 .

68. Verwey (1897), 10.

69. Verwey (1888), 8.

70. Verwey $(1889 \mathrm{~A}), 238$.

71. Verwey $(1889 \mathrm{~A}), 229$.

72. Verwey (1897), 67. Zie ook De Vooys (1935).

73. Verwey (1897), 66.

74. Zie Tollebeek (2011) en Van Halsema (2010).

75. Hanot (1957), 95.

76. Verwey (1897), 7.

77. Verwey (1956), 262.

78. Verwey (1956), 263 .

79. Verwey (1956), 262.

8o. Verwey (1956), 121.

81. Verwey (1956), 121-122.

82. Ibidem.

83. Verwey (1956), 266.

84. Ibidem.

85. Uitgeschreven toespraak van Verwey voor zijn eerste college opgenomen in Uyldert (1995), 140.

86. Albert Verwey-archief: XLI A 29:34.

87. Ibidem. 
88. Ibidem.

89. Van Dijk (2009), 278.

9o. Een uitwerking voert hier te ver, maar een en ander zou in verband gebracht kunnen worden met het veranderende literaire klimaat en de voorkeur die auteurs als Eddy du Perron en Menno ter Braak in het Interbellum aan de dag legden voor het kritische essay.

91. Verwey (1956), 267 .

92. Verwey (1956), 254 .

93. Verwey (1956), 255.

94. Verwey-archief: XLI A 41: $10 \mathrm{t} / \mathrm{m} 12$.

95. Verwey-archief: XLI A 29:34.

96. De bibliografie van Hanot (1957) laat zien dat er met regelmaat reacties verschenen vanuit publieke en academische hoek op Verweys publicaties tijdens zijn hoogleraarstijd. Met name de reacties op zijn Vondeluitgave zouden de moeite waard zijn om nauwkeuriger onder de loep te nemen.

97. De Vooys (1935), 197-198.

98. Brom (1944), 156.

99. Brom (1944), 160. Ook in een korte beschouwing 'Over den stijl van Prof.dr. Albert Verwey' prees P.H. Ritter jr. zowel Verweys gevoeligheid en dichterlijkheid als de 'superieure verstands-redelijkheid'. Ritter (1928), 45.

100. Brom (1944), 156 .

101. Liauw \& Van de Zande (1996), 103.

102. Liauw \& Van de Zande presenteren hier een visie die met name Te Winkel was toegedaan en die, zo mogen we concluderen, door Verwey met succes was bestreden. Zie ook Tollebeek (2011).

103. In retrospectief kunnen we vaststellen dat op het gebied van het wetenschappelijk onderzoek de Universiteit van Leiden met de benoeming van Verwey iemand omarmde die het literaire werk in internationale, 'europeesche' context wenste te plaatsen. Anders dan sinds Jonckbloet gebruikelijk was, was de academische literatuurstudie er volgens Verwey niet om de nationaliteitszin aan te wakkeren. Het zou echter verder onderzocht moeten worden in hoeverre Verwey op dit gebied daadwerkelijk invloed heeft uitgeoefend.

104. Verwey-archief: XLI A 29:34.

105. Hiermee wordt overigens amper recht gedaan aan de complexiteit van Verweys gebruik van het begrip. Voor een uitvoerige analyse van het verbeeldings-begrip bij Verwey zie Johannes (1992). Custers (1995) wijst er op dat Verwey in zijn hoogleraarstijd het begrip gaat combineren met de term 'waarheid'.

106. Verwey (1956), 26.

107. Te denken valt hier vooral aan een verwantschap met de hermeneutiek van Schleiermacher, zie Leezenberg \& De Vries (2001).

108. Zie Laan (1997). Eerder schreef ik over de tweeledige taakopvatting bij Jonckbloet in Winkler (2013).

109. Liauw \& Van de Zande (1996), 103.

110. Laan (1997), 274.

111. Ibidem.

112. De Geest (1996), 12.

113. De Geest (1996), 14 .

114. Deze observatie sluit aan bij observaties van de Engelse literatuurwetenschapper James F. English. In zijn artikel 'Everywhere and Nowhere: the Sociology of Literature 
after "the Sociology of Literature"' (2010) stelt hij dat er na de jaren tachtig een einde komt aan het 'paradigm of criticism'. Daarvoor in de plaats zouden we nu in een 'paradigm of discription' zitten. English schrijft deze verandering o.a. toe aan de invloed van sociologische inzichten en methodieken in de literatuurstudie.

115. Nog steeds is de oogst niet groot. Belangrijkste referentiepunten blijven: Liauw \& Van de Zande (1996), Goedegebuure en Heynders (1996), De Vries (1997) en sinds 2011 dus Tollebeeks Mannen van karakter. Er bestaan enkele universiteitsgeschiedenissen maar die zijn altijd lokaal. Joosten (1998) behandelt de geschiedenis van het Nijmeegse instituut Nederlands; Willem Otterspeer (2000-2005) de geschiedenis van de Universiteit Leiden. De tijdschriften Literatuur en Internationale Neerlandistiek besteedden in respectievelijk 1989 en 2012 een themanummer aan de vakgeschiedenis. Brems e.a. (1998) bevat de bijdragen van het Dertiende Colloquium Neerlandicum gewijd aan 200 jaar neerlandistiek. De meeste publicaties zijn echter meer aanzetten dan uitgebreide systematische studies op het gebied van de vakgeschiedenis. Het overzichtswerk van Nico Laan is dat wel, maar is weer niet speciaal op de situatie in Nederland gericht.

\section{Bibliografie}

Abma, Ruud, Over de grenzen van disciplines. Plaatsbepaling van de sociale wetenschappen, Vantilt, Nijmegen, 2011 .

Anbeek, Ton, 'Liaisons Dangereuses. Literatuurstudie tussen kunst en wetenschap', in: De Vries (1997), 84-97.

Bod, Rens, De vergeten wetenschappen. Een geschiedenis van de humaniora, Bert Bakker, Amsterdam, 2010.

Brems, Hugo, Gerard Elschout, Anne Marie Musschoot, Roel Vismans (red.), Nederlands 200 jaar later, Internationale Vereniging voor Neerlandistiek, Woubrugge, 1998.

Brom, Gerard, Geschiedschrijvers van onze letterkunde, Elsevier, Amsterdam, 1944.

Custers, Lucien, Dáár was de bron. De Beweging van Tachtig in de ogen van Albert Verwey, Uitgeverij De Ploeg, Maarssen, 1995.

Dijk, Annette van, 'Welk een ketter is die vrouw geweest!' De plaats van Albert Verwey in de Hadewijchreceptie, Verloren, Hilversum, 2009.

Dorleijn, Gillis, 'De plaats van tekstanalyse in een institutioneel-poëticale benadering', in: Nederlandse Letterkunde 14, 2009, nr. 1, 1-19.

Dorleijn, Gilles \& Kees van Rees (red.), De productie van literatuur. Het literaire veld in Nederland 1800-200o, Vantilt, Nijmegen, 2006.

English, James F., 'Everywhere and Nowhere: The Sociology of Literature After "the Sociology of Literature"', in: New Literary History 41, 2010, nr. 2, v-xxiii.

Fokkema, Douwe \& Elrud Ibsch, 'Literaire kritiek. Touwtrekken om de tekst - de verschillende werkterreinen van de criticus en de wetenschapper', in: Douwe Fokkema \& Elrud Ibsch, Literatuurwetenschap \& cultuuroverdracht, Countinho, Muiderberg, 1992, 24-34.

Geest, Dirk de, Literatuur als systeem, literatuur als vertoog. Bouwstenen voor een functionalistische benadering van literaire verschijnselen, Peeters, Leuven, 1996.

Gerritsen, W.P., C.G.N. de Vooys en de explosie van de neerlandistiek, Universiteit Utrecht, Utrecht, 1995 . 
Goedegebuure, Jaap \& Odile Heynders, Literatuurwetenschap in Nederland: een vakgeschiedenis, AUP, Amsterdam, 1996.

Goldmann, Mario, Jens Köhrsen, Reinhard Schulz, Dirk Thomaschke (red.), Wozu noch Geisteswissenschaften?, BIS-Verlag, Oldenburg, 2007.

Gossaert, Geerten, 'Pieter Nicolaas van Eyck', in:Jaarboek van de Maatschappij der Nederlandsche Letterkunde te Leiden 1956-1957, E.J. Brill, Leiden, 1957, 42-57.

Graff, Gerald, Professing Literature. An Institutional History, 2oth edition, The University of Chicago Press, Chicago/London, 2007 (1987).

Haeringen, C.B. van, 'Levensberichten - C.G.N. de Vooys', in: Jaarboek van de Maatschappij der Nederlandsche Letterkunde 1955-1956, E.J. Brill, Leiden, 1956, 27-38.

Halsema, J.D.F. van, “'Voelers" en "weters" - Albert Verwey en de literatuurgeschiedschrijving van Jonckbloet en Kalff, in: idem, Vrienden en Visioenen. Een biografie van Tachtig, Historische uitgeverij, Groningen, 2010, 369-385.

Hanot, M., De beginselen van Albert Verweys literaire kritiek, Koninklijke Vlaamse Academie voor Taal- en Letterkunde Reeks VI., Nr. 78, Secretariaat der Academie, Gent, 1957.

Johannes, G.J., Geduchte verbeeldingskracht! Een onderzoek naar het literaire denken over de verbeelding - van Van Alphen tot Verwey, Academisch proefschrift, Universiteit Utrecht, Utrecht, 1992.

Johannes, G.J., "Nationale filologieën" en het historisch onderzoek naar disciplinevorming in de geesteswetenschappen. Een verkenning', in: Studium 1, 2011, 31-46.

Joosten, Jos, Lijnen en breuken. Een kleine historische beschouwing over het Nijmeegse Instituut Nederlands, Vantilt, Nijmegen, 1998.

Laan, Nico, Het belang van smaak. Twee eeuwen academische literatuurgeschiedenis, Historisch Seminarium van de Universiteit van Amsterdam, Amsterdam, 1997.

Leezenberg, M. \& G. de Vries, Wetenschapsfilosofie voor geesteswetenschappen, AUP, Amsterdam, 2001.

Liauw, Menno \& Leon van de Zande, Aan doorluchtige voorgangers hapert het niet: een geschiedenis van de neerlandistiek, Universiteit Utrecht, Utrecht, 1996.

Luger, B., 'G. Kalff. Bloem en vrucht', in: Literatuur 6, 1989, 337-340.

Nijland-Verwey, M. (red.), Albert Verwey. Keuze uit het proza van zijn hoogleraarstijd (1925-1935), Uitgeversmaatschappij W.E.J. Tjeenk Willink, Zwolle, 1956.

Oostrom, Frits van, 'Jonckbloet de grondlegger', in: Literatuur 6, 1989, 325-328.

Otterspeer, Willem, Groepsportret met dame I-III, Bert Bakker, Amsterdam, 2000-2005.

Praamstra, O., 'De analyse van kritieken', in: Voortgang. Jaarboek voor de neerlandistiek 5, 1984, 241-264.

Ritter, P.H. jr., 'Over de stijl van Prof.dr. Albert Verwey', in: Ritter, P.H. jr., De kritische reis, Uitgeversmaatschappij Holland, Amsterdam, 1928, 44-48.

Rosengren, Karl Erik, 'Literary Criticism: Future Invented', in: Poetics 13, 1987, nr. 3-4, 295-325.

Smit, W.A.P., 'Inleiding', in: Nijland-Verwey (1956), 5-9.

Spies, Marijke, 'Van mythes en meningen: over de geschiedenis van de literatuurgeschiedenis', in: idem (red.), Historische letterkunde. Facetten van vakbeoefening, Wolters-Noordhoff, Groningen, 1984, 171-193.

Tollebeek, Jo, Mannen van karakter. De wording van de moderne geesteswetenschappen, Bert Bakker, Amsterdam, 2011.

Uyldert, M., Naar de voltooiing. Uit het leven van Albert Verwey III, A. Sijthoff N.V., 's Gravenhage, 1959 .

Verstraeten, Pieter, Het discours van de kritiek. Literaire kritiek in Vlaanderen tussen de twee wereldoorlogen: Joris Eeckhout, Urbain van de Voorde, Paul de Vree, Garant, Antwerpen/ Apeldoorn, 2011. 
Verwey, Albert, Toen De Gids werd opgericht... Scheltema \& Holkema's Boekhandel, Amsterdam, 1897 (1887).

Verwey, Albert, 'Het twintigste Taal- en Letterkunde congres', in: De Nieuwe Gids 3, 1888, 1-11.

Verwey, Albert, 'BOEKBEOORDEELINGEN. een leelijk eendje, Jan ten Brink, Brederoo, Heine en Hélène Swarth', in: De Nieuwe Gids 4, 1889a, 211-242.

Verwey, Albert, 'Bij den dood van J.A. Alberdingk Thijm', in: De Nieuwe Gids 4, 1889b, 224-231.

Verwey, Albert, 'Jan ten Brinks Geschiedenis der Nederlandse letterkunde. (Brief aan een vriend)', (1897), in: idem, Proza V, Querido, Amsterdam, 1922, 66-74.

Verwey, Albert, Stille Toernooien, W. Versluys, Amsterdam, 1901.

Verwey, Albert, 'Oude en nieuwe idee in de geschiedenis van onze letteren', (1910), in: idem, Proza $V$, Querido, Amsterdam, 1922, 85-94.

Verwey, Albert, 'Dr. C.G.N. de Vooys: wording en verwording van letterkundige taal', (1915), in: idem, Proza X, Querido, Amsterdam, 1923, 45-51.

Verwey, Albert, 'Van Jacques Perk tot nu', (1925), in: Nijland-Verwey (1956), 12-33.

Verwey, Albert, 'Vondel', (1926), in: Nijland-Verwey (1956), 121-123.

Verwey, Albert, 'Het lezen en schatten van gedichten', (1935), in: Nijland-Verwey (1956), 253-268.

Vooys, C.G.N. de, 'Verwey's verdienste voor de Nederlandse litteratuurstudie', in: De Nieuwe Taalgids 29, 1935, speciaal Verwey-nummer ter gelegenheid van het afscheid van Verwey als hoogleraar, 193-200.

Vooys, C.G.N. de, 'Albert Verwey en de Nederlandse litteratuurwetenschap', in: De Stem XVII, 1937, nr. 7/8, speciaal nummer ter herdenking van Albert Verwey, onder redactie van Dirk Coster en Anthonie Donker, 777-784.

Voskuil, Menno, 'De hoogleraar die weigerde... Albert Verwey (1865-1937) en de Maatschappij der Nederlandse Letterkunde', in: Nieuw Letterkundig Magazijn xxx, 2012, nr. 1, 28-30.

Vries, Jan W. de (red.), 'Eene bedenkelijke nieuwigheid.' Twee eeuwen neerlandistiek, Verloren, Hilversum, 1997.

Winkler, Marieke, 'Interpretatie en/of patroon? Over Het einde van de geesteswetenschappen 1.0 en het onderscheid tussen kritiek en wetenschap', in: Vooys 31, 2013, nr. 1, 31-41.

\title{
Archiefstukken uit het Albert Verwey-archief (UvA)
}

\author{
XLI A 23:69 \\ XLI A 29:34 \\ XLI A 31:1 \\ XLI A 31:46 \\ XLI A 41:10-12 \\ XLI A 49:17
}

\section{Over de auteur}

Marieke Winkler is als promovenda verbonden aan de afdeling Nederlandse Taal en Cultuur van de Radboud Universiteit Nijmegen. Zij werkt aan een proefschrift over het onderscheid tussen literatuurkritiek en literatuurwetenschap in de Nederlandse letteren sinds 1900. 